\title{
MODIFIKASI KEBAYA BERBAHAN DASAR ENDEK DENGAN APLIKASI BORDIR
}

\author{
N. L. A.Utami ${ }^{1}$, I. G. Sudirtha ${ }^{2}$, M. D. Angendari ${ }^{3}$ \\ Jurusan Teknologi Industri, Fakultas Teknik dan Kejuruan \\ Universitas Pendidikan Ganesha \\ Singaraja, Indonesia \\ e-mail: tamiayux1@gmail.com, gede.sudirtha@undiksha.ac.id, \\ diah.angendari@undiksha.ac.id
}

\begin{abstract}
Abstrak
Tujuan dari penelitian ini yaitu untuk mendeskripsikan hasil pengembangan dari modifikasi kebaya berbahan dasar endek dengan aplikasi bordir berdasarkan prinsip keselarasan, keseimbangan, irama, dan proporsi. Penelitian ini menggunakan model pengembangan PPE (Planning, Production, and Evaluation), dimulai dari tahap perencanaan, produksi, dan evaluasi produk. Dalam penelitian ini dilibatkan dua orang ahli isi untuk menguji instrumen dan tiga orang ahli busana untuk menguji kualitas produk yang dihasilkan. Setelah instrumen dinyatakan valid, instrumen tersebut digunakan untuk uji produk. Penilaian produk dinilai berdasarkan prinsip desain yaitu keselarasan, keseimbangan, irama, dan proporsi, dengan tingkat pencapaian sesuai dengan kriteria yang ditentukan. Berdasarkan uji produk yang telah dilakukan oleh ahli busana, mendapatkan hasil 100\% dari ahli busana 1, $93,33 \%$ dari ahli busana 2, dan 93,33\% dari ahli busana 3 . Rata-rata presentase menunjukkan bahwa hasil pengembangan dari modifikasi kebaya berbahan dasar endek dengan motif bordir memiliki kualifikasi yang sangat baik dengan rata-rata $95,55 \%$.
\end{abstract}

Kata Kunci: Modifikasi, Kebaya, Kain Endek, Motif Patra Sari

\begin{abstract}
The purpose of this study was to describe the results of the development of kebaya modification were made from Endek base with embroidery motif based on the principle of harmony, balance, rhythm, and proportion. This study uses the development model of PPE (Planning, Production, and Evaluation), started from the planning, production and product evaluation stages. In this study, two content experts were involved to test the instrument and three fashion experts to test the quality of the products produced. After the instrument was declared valid, the instrument was used for product testing. Product assessment was assessed based on design principles, namely harmony, balance, rhythm, and proportion, with the level of achievement by the specified criteria. Based on product tests conducted by fashion experts, getting 100\% from fashion experts 1, 93.33\% from fashion experts 2 , and $93.33 \%$ from fashion experts 3 . The average percentage shows that the results of the development of kebaya modification were made from Endek base with embroidery motif had been very good qualifications with an average of $95.55 \%$.
\end{abstract}

Keywords: Modification, Kebaya, Endek, Patra Sari Motif 


\section{PENDAHULUAN}

Bali dengan mayoritas masyarakat Hindu tidak terlepas dari penggunaan kebaya. Selain digunakan sebagai busana persembahyangan, kebaya juga digunakan sebagai busana wisuda, pernikahan, dan sebagainya. Meningkatnya penggunaan kebaya di Bali didorong dengan adanya Peraturan gubernur Bali No 79 tahun 2018 tentang Hari Penggunaan Busana Adat Bali, yaitu pada hari Kamis, Purnama, Tilem, dan Hari Jadi Provinsi Bali pada tanggal 14 Agustus. Penggunaan kebaya pada hari kamis, purnama, tilem, dan hari jadi provinsi bali wajib dilakukan di lingkungan lemaga pemerintahan dan lembaga swasta. Kebaya yang digunakan harus sesuai dengan etika dan kesopanan berbusana.

Kebaya merupakan salah satu busana nasional yang dapat menjadi identitas budaya Indonesia (Ltifah, 2011:1). Pada umumnya kebaya digunakan pada acara-acara adat dan kenegaraan tertentu. Sementara penggunaan kebaya di Bali lebih sering digunakan dalam acara persembahyangan bagi umat Hindu.

Seiring perkembangan zaman, kebaya terus mengalami perkembangan. Perkembangan kebaya dilakukan baik dari segi modifikasi model, bahan dasar, hingga hiasan kebaya. Model kebaya yang beraneka ragam akan mempengaruhi pemilihan bahan dasar yang akan digunakan. Bahan dasar dalam membuat kebaya dipilih dan dikombinasikan sedemikian rupa sesuai dengan desain yang dibuat. Modifikasi kebaya dari segi bahan dasar sangat terlihat dari kreativitas masyarakat dalam mengkombinasikan bahan dasar. Bahan dasar kebaya yang polos dikombinasikan dengan kain bermotif atau berokat, kain berokat dikombinasikan dengan kain tile, dan masih banyak lagi jenis kombinasi bahan dasar. Selain itu, hiasan kebaya juga sangat beraneka ragam, mulai dari hiasan bordir, sulam, painting, payet, mutiara, manik-manik, dan lain sebagainya.

Banyak masyarakat memilih untuk menggunakan kebaya yang telah dimodifikasi dibandingkan dengan kebaya dengan model kartini atau kutu baru dengan bahan yang polos. Pada zaman sekarang masyarakat lebih mementingkan estetika tanpa peduli dengan etika berbusana. Masyarakat lebih suka mengikuti gaya berbusana sesuai dengan trend (I Dewa Ayu Sri Sulasmini, 2017). Hal ini dikarenakan model kebaya modifikasi menyajikan berbagai jenis kebaya yang unik sehingga dapat menarik perharian masyarakat. Tidak hanya pada kalangan remaja, banyak ibu-ibu yang tidak kalah menggunakan kebaya modifikasi. Menggunakan kebaya modifikasi boleh dilakukan, namun tetap memperhatikan nilai kesopanan dalam berbusana.

Modifikasi pada kebaya telah banyak dilakukan. Modifikasi merupakan cara merubah, menggayakan, menambah/ menyederhanakan bentuk, memadukan aneka bahan, mengatur ulang komposisi warna, motif, dan menciptakan hal baru yang sangat berbeda dari asalnya (Nanang Ajim, 2015). Pada penelitian ini modifikasi yang dilakukan berupa merubah kebaya ke arah yang lebih sopan dengan ide-ide baru yang kreatif. Pada (Indopus, 2017) dijelaskan bahwa kebaya awalnya memiliki dua bentuk dasar yaitu kartini dan kutu baru, dan menggunakan bahan yang polos Kebaya kartini adalah kebaya yang dikenakan pada masa R. A. Kartini. Model kebaya kartini memiliki lipatan pada bagian dada. Panjang kebaya yang menutup panggul, dan lipatan kerah dengan bentuk garis vertikal, yang memberi kesan tinggi dan ramping pada pemakainya. Sedangkan kebaya kutu baru yaitu memiliki tambahan kain untuk menghubungkan sisi kiri dan kanan kebaya di bagian dada dan perut (Andika, 2018).

Adanya modifikasi melahirkan banyak jenis model kebaya seperti kebaya dengan lengan pendek, kebaya dengan bahan brokat, kebaya dengan tile kombinasi brokat, dan sebagainya. Modifikasi kebaya pada zaman sekarang sudah meninggalkan etika berbusana. Banyaknya jenis modifikasi kebaya, tidak boleh terlepas dari pakem kebaya, yaitu memiliki siluet yeng membentuk tubuh pemakai. Selain itu etika berbusana juga tidak boleh dilupakan. Hal ini sudah ditegaskan kembali pada Peraturan Gubernur Bali No 79 tahun 2018 Bab III Pasal 4 yang menyebutkan penggunaan 
busana adat Bali sesuai dengan nilai kesopanan, kesatuan, kepatuhan, dan kepantasan yang berlaku di masyarakat.

Oleh karena itu, perlu adanya modifikasi baru pada kebaya yang dapat menonjolkan etika dan estetika berbusana. $\mathrm{Hal}$ yang dapat dilakukan yaitu dengan cara memodifikasi kebaya dengan bahan yang tidak tembus pandang dan juga dengan model yang sopan. Salah satu bahan yang dapat digunakan yaitu kain endek. Kain endek adalah kain tenun khas Bali yang merupakan kerajinan khas Klungkung (Latifah, 2012:30).

Menggunakan kain endek sebagai kebaya, bertujuan untuk meningkatkan eksistensi penggunaan kain endek. Hal ini sudah diatur dalam Peraturan Gubernur Bali No 79 tahun 2018. Pada Bab II pasal 4 ayat 3 disebutkan bahwa unsur Busana Adat Bali sebagaimana dimaksud pada ayat 1 dan 2 menggunakan produk lokal Bali sehingga dipilihlah kain endek sebagai bahan dasar kebaya. Untuk memperindah kain endek sebagai kebaya, perlu adanya modifikasi pada kain tersebut. Modifikasi dapat dilakukan dengan cara menambahkan aplikasi bordir pada kebaya. Bordir adalah teknik menghias kain dengan menitikberatkan keindahan motif dan komposisi warna benang pada medium berbagai kain dengan alat bantu seperangkat mesin jahit bordir atau mesin jahit bordir komputer (Hery Suhersono, 2004).

Motif bordir yang diaplikasikan yaitu motif pepatraan Bali. Pepatraan Bali yaitu ukiran yang mengambil tema tanaman memiliki ciri khas yaitu berbentuk cembung dan cekung (Rantinah Sastra, 2009: 33). Motif Pepatraan Bali terdiri dari beberapa motif, motif yang dipilih adalah motif patra sari. Motif patra sari dipilih karena motif ini memiliki bentuk yang unik seperti sari bunga dengan bentuk berbatang jalar dan meingkar-lingkar timbal balik berulangulang. Dengan bentuk motif yang sedemikian rupa, motif patra sari cocok ditempatkan pada bidang-bidang penempatan motif kebaya. Navita, 2015 menyatakan bidang-bidang penempatan motif meliputi hiasan batas, hiasan sudut, hiasan pusat, hiasan tengah sisi, hubungan pusat dengan tengah sisi, hubungan pusat dengan sudut, hubungan sudut dengan batas, hiasan kitiran, serta hiasan arah istimewa.

Memadukan kain endek dengan motif bordir memerlukan kreativitas yang tinggi. Kain endek yang sudah memiliki motif tersendiri yaitu motif geometris akan dipadukan dengan motif bordir yang bertentangan seperti motif pepatraan Bali. Hal ini memerlukan teknik tersendiri untuk memadukan kedua motif dalam satu busana. Perpaduan dari kedua motif yang sangat bertentangan dapat memberikan nuansa baru pada motif tersebut.

Fimela, 2013 menjelaskan teknikteknik memadukan motif yaitu, memadukan motif seperti motif bunga dapat dilakukan dengan cara memadukan motif yang memiliki nuansa yang sama namun memiliki tingkatan warna yang berbeda. Selain itu memadukan motif dengan cara bold and thin yaitu dilakukan dengan memberi pembeda dari segi warna yaitu dengan memadukan warna yang gelap dan terang. Untuk memadukan motif yang jelas berbeda, maka pilihlah warna yang netral. Cara lain untuk memadukan motif yang berbeda juga dapat dilakukan dengan mix match color range yaitu memilih tingkatan warna yang sama yaitu dengan cara memadukan tingkatan gelap terang warna.

Memadukan motif dengan cara perpaduan warna dapat dilakukan dengan perpaduan warna sesuai dengan lingkaran warna. Diyah Janu Hardani (2013) menyatakan perpaduan warna dalam lingkaran warna meliputi kontras komplementer, kontras split komplementer, kontras triad komplementer, serta tetrad komplementer. Warna kontras komplementer merupakan perpaduan warna yang saling bersebrangan (sudut $180^{\circ}$ ) di lingkaran warna. Kontras split komplementer merupakan perpaduan warna yang agak bersebrangan (sudut mendekati $180^{\circ}$ namun tidak mencapai $180^{\circ}$ ). Kontras triad komplementer merupakan perpaduan tiga warna yang membentuk segi tiga sama kaki pada lingkaran warna (sudut $60^{\circ}$ ). Tetrad komplementer merupakan perpaduan empat warna yang membentuk bangun segi empat (dengan sudut $90^{\circ}$ ). 
Komposisi warna harmonis dibuat menggunakan warna-warna yang selaras seperti Komposisi warna analogus merupakan komposisi warna yang saling berdekatan pada lingkaran warna. Komposisi warna monokromatik merupakan komposisi warna yang terdiri dari satu warna namun memiliki tingkat gelap terang. Komposisi warna tersier dan kuarter merupakan warna campuran sehingga mengarah pada warna-warna cokelat.

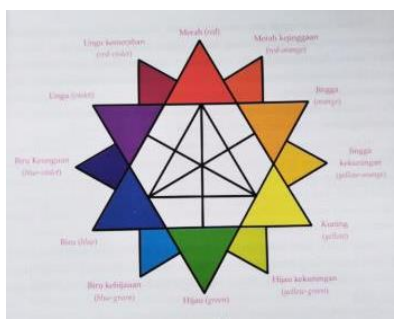

Gambar 1 Lingkaran Warna

Sumber: Diyah Janu Hardani, 2013

Penelitian ini merupakan penelitian pengembangan deskritif kuantitatif dan kualitatif mengenai modifikasi kebaya berbahan dasar endek dengan aplikasi bordir, dengan tujuan Untuk mengetahui hasil pengembangan dari modifikasi kebaya berbahan dasar endek dengan aplikasi bordir berdasarkan prinsip keselarasan, keseimbangan, irama, dan proporsi.

\section{METODE PENELITIAN}

Metode penelitian yang digunakan pada penelitian ini yaitu metode pengembangan PPE (Planning, Production, and Evaluation). Planning meliputi kegiatan perencanaan produk yang akan dibuat, sebelumnya perencanaan diawali dengan analisis kebutuhan yang dilakukan melalui penelitian. Production yaitu kegiatan memproduksi atau membuat produk yang telah dirancang sebelumnnya. Evaluation merupakan kegiatan mengevaluasi atau menguji, menilai, seberapa tinggi produk telah memenuhi spesifikasi yang telah ditentukan Sugiyono (2017:35). Pengupulan data hasil penelitian pengembangan ini yaitu menggunakan satu metode yaitu kuisioner. Angket atau kuesioner merupakan teknik pengumpulan data yang dilakukan dengan cara memberi seperangkat pertanyaan tertulis kepada responden untuk dijawab (Sugiyono, 2009:199).

\section{HASIL DAN PEMBAHASAN Hasil Penelitian}

Pengembangan modifikasi kebaya berbahan dasar endek dengan aplikasi bordir dilakukan sesuai dengan langkahlangkah pengembangan PPE (Planning, Production, and Evaluation). Planning merupakan proses perencanaan produk yang meliputi proses analisis dan dilanjutkan dengan proses mendesain. Produk yang dibuat yaitu kebaya, berbahan dasar kain endek dengan dengan motif endek yang tidak menonjol. Motif kain endek berbentuk kecil-kecil dengan warna yang senada antara motif dengan warna dasar kain. Motif bordir yang diaplikasikan yaitu motif pepatraan Bali yaitu motif patra sari.

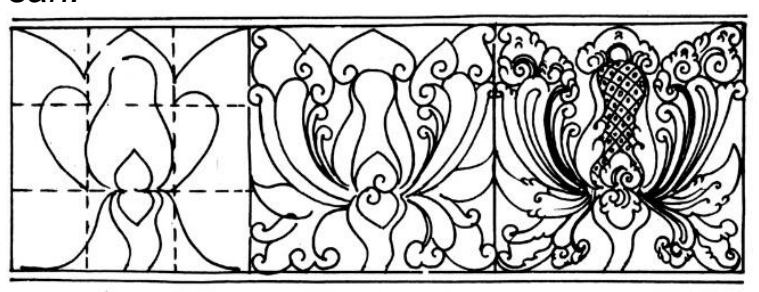

Gambar 2. Motif Patra Sari Sumber:

https://serbaserbihindubali.blogspot.com

Proses mendesain dilakukan sesuai dengan analisis produk. Terlebih dahulu dibuat beberapa desain sketsa. Atas beberapa pertimbangan dipilih salah satu desain dari beberapa desain yang telah dibuat.

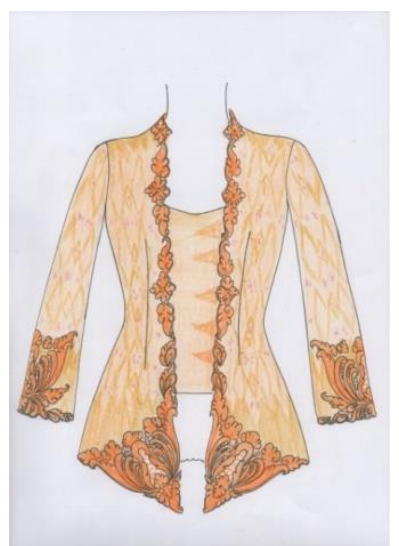

Gambar 3 Desain Kebaya Tampak Depan Sumber: Dokumentasi Pribadi 


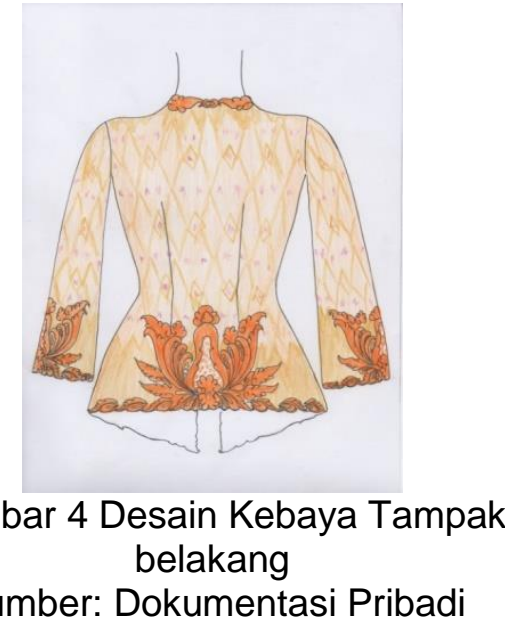

Berdasarkan desain yang dipilih, produk yang dibuat yaitu kebaya dengan model kutu baru. Bahan dasar yang digunakan yaitu kain endek dengan motif cepuk berwarna jingga tua dengan motif berwarna jingga muda. Dikombinasikan dengan motif bordir pepatraan Bali yaitu motif patra sari berwarna oranye.

Pada tahap production (produksi) dilakukan dengan tiga tahapan yaitu persiapan, tahap membordir, dan tahap membuat kebaya. Tahap persiapan meliputi pengambilan ukuran model, pembuatan pola, merancang bahan, serta menyiapkan kebutuhan lainnya yang diperlukan untuk membordir dan menjahit. Tahap membordir dimulai dari menjiplak pola motif pada kain endek sesuai dengan desain. Sebelumnya motif digambar pada bidang kertas minyak sesuai dengan penempatan motif pada desain. Kemudian pola motif tersebut dijiplak pada kain sesuai dengan penempatan yang telah ditentukan. Penjiplakan motif pada kain endek dilakukan dengan bantuan karbon jahit agar pola tergambar jelas pada kain. Setelah pola motif terjiplak, barulah masuk ketahap membordir. Pada tahap pembordiran tentukan benang bordir yang akan digunakan. Sebelumnya cek mesin yang akan digunakan sehingga pada saat membordir tidak terjadi kerusakan. Membordir dilakukan sesuai dengan desain motif dengan teknik bordir yang telah ditentukan. Tahap membuat kebaya mencakup tahap pemotongan, tahap menjahit kebaya, serta tahap penyelesaian.
Tahap evaluation (evaluasi) dilakukan pada keseluruhan bagian produk. Evaluasi dimulai dari tahap pengecekan hasil akhir produk sebelum dilanjutkan pada tahap uji produk, dan tahap perbaikan. Uji produk dilakukan oleh tiga orang ahli busana yaitu, Ibu Putu Ria Yusnita selaku owner Ria Boutique, Ibu Luh Nusari, S.Pd., M.Pd, selaku staf pengajar di SMK N 2 Singaraja dan Luh Putu Ari Sukreni, S.Pd, selaku staf pengajar di SMK N 1 Seririt. Hal-hal yang dinilai pada uji produk sudah ditentukan dan sudah tertera pada instrumen penelitian. Berikut merupakan hasil dari uji produk modifikasi kebaya berbahan dasar endek dengan aplikasi bordir.

Tabel 1. Hasil Uji Produk

\begin{tabular}{|c|c|c|c|c|c|}
\hline Indikator & $\begin{array}{c}\text { Skor } \\
\text { Maksimal }\end{array}$ & $\begin{array}{c}\text { Jumlah } \\
\text { Butir }\end{array}$ & $\begin{array}{c}\text { Ahli } \\
\text { Busana } \\
1\end{array}$ & $\begin{array}{c}\text { Ahli } \\
\text { Busana } \\
2\end{array}$ & $\begin{array}{c}\text { Ahli } \\
\text { Busana } \\
3\end{array}$ \\
\hline 1 & 3 & 1 & 3 & 3 & 3 \\
\hline 2 & 3 & 1 & 3 & 3 & 3 \\
\hline 3 & 3 & 1 & 3 & 3 & 3 \\
\hline 4 & 6 & 2 & 6 & 5 & 5 \\
\hline \multicolumn{3}{|c|}{ Skor Perolehan } & 15 & 14 & 14 \\
\hline \multicolumn{3}{|c|}{ Skor Maksimal } & 15 & 15 & 15 \\
\hline \multicolumn{3}{|c|}{ Presentase } & $100 \%$ & $93,33 \%$ & $93,33 \%$ \\
\hline
\end{tabular}

Berdasarkan data yang telah diperoeh dalam uji produk oleh 3 orang ahli busana, selanjutnya data dianalisis berdasarkan rumus dari Tegeh, dkk (2014).

$$
\begin{aligned}
& \text { Presentase }=\frac{\sum x}{\text { SMI }} \times 100 \% \\
& \text { Presentase }=\frac{15}{15} \times 100 \%=100,00 \% \\
& \text { Presentase }=\frac{14}{15} \times 100 \%=93,33 \% \\
& \text { Presentase }=\frac{14}{15} \times 100 \%=93,33 \% \\
& \text { Rata-rata }=\frac{286,66}{3} \times 100 \%=95,55 \%
\end{aligned}
$$

Dari hasil analisis data, dapat disimpulkan bahwa hasil akhir dari modifikasi kebaya berbahan dasar endek dengan aplikasi bordir memiliki kualifikasi yang sangat baik dengan konvensi tingkat pencapaian mencapai 95,55\%. 


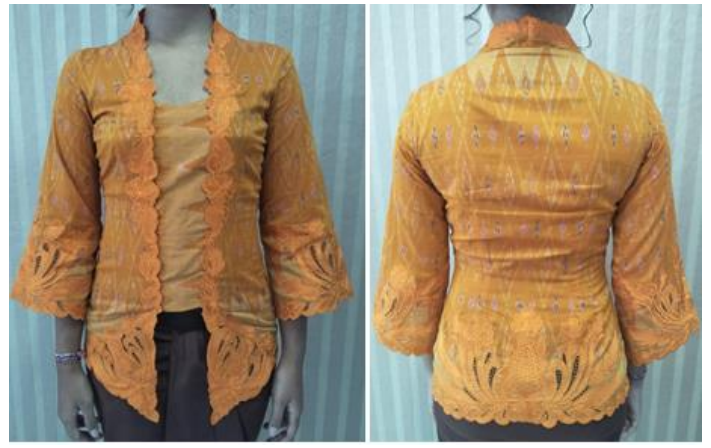

Gambar 5 Hasil Jadi Kebaya

Sumber: Dokumentasi Pribadi

\section{Pembahasan}

Pengembangan produk modifikasi kebaya berbahan dasar endek dengan aplikasi bordir memberikan nuansa baru pada kebaya dengan menggunakan kain endek yang dibordir dengan motif pepatraan Bali. Kebaya memiliki model kutu baru, berbahan dasar endek dengan motif cepuk, serta aplikasi motif bordir pepatraan Bali yaitu motif patra sari.

Dari segi keselarasan kebaya memiliki keselarasan antar bentuk motif bordir sehingga menimbulkan kesan menyatu antar motif. Selain itu keselarasan juga dinilai dari keselarasan pemilihan warna pada kain endek, motif kain endek, serta motif bordir. Sementara dari segi keseimbangan penempatan, motif bordir diletakkan secara simetris pada bagian tengah muka dan bagian lengan. Berdasarkan prinsip irama, motif bordir memiliki irama bentuk sesuai dengan bidang penempatannya. Selain itu perpaduan antara motif bordir dengan motif endek memiliki irama yang sama dari segi bentuk dan warnanya. Proporsi perpaduan antara motif endek dengan motif bordir serta proporsi motif bordir sesuai pada bidang penempatannya. Perpaduan antara motif endek dengan motif bordir, kebaya memiliki proporsi kain endek yang lebih dominan dari motif bordir, sehingga motif bordir tidak mendominasi pada kebaya. Selain itu perpaduan antara kain endek dengan motif bordir tidak menimbulkan kesan yang ramai. Sedangkan proporsi motif bordir pada bidang penempatannya, penempatan motif bordir pada bagian depan meruncing, penempatan pada bagian tengah muka hingga garis leher memiliki bentuk lurus sesuai bidangnya, serta penempatan motif bordir pada bagian belakang bawah dan lengan ditempatkan sesuai dengan bidangnya.

Berdasarkan hasil uji produk oleh ahli busana, hasil modifikasi kebaya berbahan dasar endek dengan aplikasi bordir memiliki kualifikasi sangat baik dengan tingkat pencapaian 95,55\%. Akan tetapi perlu ditambahkan kupnat sisi sebesar $3 \mathrm{~cm}$ dengan jarak penempatan 7 $\mathrm{cm}$ dari batas kerung lengan pada bagian badan depan guna menghindari kerutan pada area bawah kerung lengan.

Kebaya sudah mulai mengalami perubahan dari segi desain maupun bahan yang digunakan. Hal ini diakibatkan oleh pesatnya perkembangan teknologi, informasi, dan industri pariwisata (I Dewa Ayu Sri Suasmini, 2017). Akan tetapi perkembangan kebaya saat ini sudah mulai melupakan etika berbusana. Oleh karena itu dipandang perlu untuk mengembangkan suatu jenis kebaya yang memiliki desain yang lebih sopan baik dari segi bahan dasar, serta model kebaya yang dibuat. Endang Wani Karyaningsih (2015) menyatakan faktor-faktor yang mempengaruhi pemilihan kebaya yaitu, model kebaya, bahan/tekstil, serta variasi hiasan pada kebaya. Sehingga untuk mengajak masyarakat menggunakan busana kebaya yang lebih sopan dan beretika, kebaya perlu dimodifikasi dari segi model kebaya, bahan dasar, serta hiasan kebaya yang lebih menarik.

Membuat kebaya menjadi lebih menarik dapat dilakukan dengan mengubah bahan dasar kebaya menggunakan kain yang unik seperti kain tradisional. Ririn Pebrianti (2017) menyatakan bahwa motif kain tenun telah mengalami perkembangan. Pada ragam hias tenun Sri Menanti di Desa Kembang Kerang meliputi, ragam hias lumbung (rumah adat), ragam hias belah ketupat, ragam hias kembang nyiur (bunga kelapa, ragam hias kembang kerang (Bunga Kelapa), ragam hias burung, ragam hias gunung rinjani. Sementara Luh Putu Sri Indra Pratiwi (2016) menyatakan bahwa kain endek di Industri Putri Ayu Kecamatan Blahbatuh, Gianyar yaitu menggunakan motif pucuk (bunga kembang sepatu) yang beraneka ragam. Dengan demikian motif pada kain tradisional teah memiliki motif 
khas tersendiri, yang tidak dapat diubah secara menyeluruh. Akan tetapi boleh dikombinasikan dan dikembangkan dengan motif-motif baru.

I Gusti Ayu Melistyari Dewi, dkk (2019) menyatakan bahwa padu padan kain endek sudah mulai dilakukan, tidak hanya sebagai kain bawahan namun bisa dimodifikasi menjadi busana atasan seperti baju, dasi, dan sebagainya. Untuk itu kain endek dapat digunakan sebagai bahan dasar kebaya. Untuk memberikan nuansa baru pada kain endek, dapat dilakukan dengan kombinasi motif bordir.

Aini Lolita dan Wan Ridwan Husen (2018) menyatakan bahwa ada dua jenis proses pembuatan bordir yaitu dengan cara manual dan bordir komputer. Ririn Pebrianti (2017) menyatakan bahwa menghias kain dapat dilakukan dengan cara mengkombinasikan teknik painting dan bordir. Sementara untuk menghias kain yang sudah memiliki motif sebaiknya menggunakan satu jenis teknik menghias, seperti menggunakan teknik bordir. Menurut Aini Lolita dan Wan Ridwan Husen (2018) Motif bordir sangat bervariasi dari segi bentuk dan motif, namun tidak ada makna khusus dan simbolik dalam motif bordir yang digunakan. Sehingga untuk memberikan nuansa baru pada motif bordir perlu ada pemilihan motif yang baru dan unik. Motif yang digunakan dapat berupa motif tradisional sehingga memiliki makna yang tersendiri. Annisa Kurnia Widianti dan Anung Bambang Studyanto (2017) menyatakan bahwa makna yang terkandung pada pepatraan adalah memberikan perlindungan kepada kehidupan manusia dari rasa takut, haus, dan yang lainnya sehingga memberikan kenyamanan bagi manusia. Sehingga motif bordir yang dapat diterapkan yaitu motif pepatraan Bali yang memiliki makna dan untuk melestarikan motif khas Bali.

\section{SIMPULAN DAN SARAN}

Berdasarkan hasil pengembangan dari modifikasi kebaya berbahan dasar endek dengan aplikasi bordir, mendapatkan hasil kualifikasi yang sangat baik yaitu 95,55\% berdasarkan data uji produk dari tiga orang ahli busana. Dari hasil tersebut dapat dilihat bahwa produk yang dihasilkan masih belum sempurna dan masih memerlukan beberapa tahap perbaikan sesuai dengan masukan yang diberikan oleh ahli busana.

Berdasarkan hasil uji produk modifikasi kebaya berbahan dasar endek dengan aplikasi bordir mendapatkan kualifikasi sangat baik. Selain itu juga mendapatkan saran dari penguji yaitu perlu penambahan kupnat sisi $3 \mathrm{~cm}$ untuk meminimalisir kerutan pada area bawah kerung lengan. Dengan demikian, ini dapat dijadikan sebagai acuan dalam pengembangan dari modifikasi kebaya dengan konsep yang berbeda.

\section{DAFTAR PUSTAKA}

Ajim, Nanang. 2015. "Modifikasi Produk Kerajinan Bahan Limbah Organik" Tersedia pada http://www.mikirbae.com/2015/06/ modifikasi-produk-kerajinan-

bahan.html (diakses tanggal 3 Juni 2019).

Andika. 2018. "Mengenal Jenis-jenis Kebaya di Indonesia". Tersedia pada

http://gosocio.co.id/author/andika (diakses tanggal 22 Januari 2019).

Dewi, Melistyari, dkk. 2019. "Kreasi Ikat Endek Sebagai Produk Penunjang Pariwisata Bali". Jumpa, Volume 05, Nomor 02.

Fimela. 2013. "Trik Memadukan Motif Busana Printing". Tersedia pada https://www.fimela.com/beautyhealth/read/3722788/trikmemadukan-motif-busana-printing (diakses tanggal 1 Mei 2019).

Hardani, Diyah J. 2013. Menghias Busana dengan Manipulasi Kain. Seleman: PT Intan Sejati Klaten.

Indopus. 2017. "Tren Kebaya, Modern Boleh tapi Harus Sesuai Pakem". Tersedia pada: https://indopos.co.id/read/2017/03/ 23/92235/tren-kebaya-modernboleh-tapi-harus-sesuai-pakem (diakses tanggal 27 Februari 2019).

Karyaningsih, Endang W. 2015. "FaktorFaktor yang Mempengaruhi Pemilihan Kebaya pada Ibu-lbu 
dan Remaja Putri". Keluarga, Volume 1, Nomor 1.

Latifah, I. 2012. "Busana Tenun Nusantara" Sleman: KTSP.

Latifah, I. 2011. " Kreasi Kebaya" Sleman: KTSP.

Lolita, A., dan Husan, W. R. 2018. "Variasi Bentuk dan Makna Motif Bordir di Sentra Bordir Kecamatan Kawalu Kota Tasikmalaya" Pendidikan dan Kajian Seni, Volume 3, Nomor 2.

Navita. 2015. "Pola Hiasan Busana" Tersedia pada http://kursusjahityogya.blogspot.co m/2015/09/contohmotifpinggiran.html (diakses tanggal 1 Mei 2019).

Pebrianti, Ririn. 2017." Penerapan Motif Hias pada Kain Jadi dengan Menggunakan Kombinasi Teknik Painting dan Bordir". Undiksha, Volume 8, Nomor 2.

Peraturan Gubernur Bali Nomor 79 Tahun 2018 tentang Hari Penggunaan Busana Adat Bali.

Pratiwi, Sri Indra. 2016. "Deskripsi Tentang Tenun Endek Motif Pucuk pada Industri Tenun Putri Ayu Kecamatan Blahbatuh Kecamatan Gianyar". Undiksha, Volume 5, Nomor 2.

Sastra, Rantinah. 2009. Ragam Hias Nusantara. Klaten: PT. Macanan Jaya Cemerlang.

Sugiyono. 2009. Metode Penelitian Pendidikan Pendekatan Kuantitatif, Kualitatif, dan R\&D. Bandung: Alfabeta.

Sugiyono. 2017. Metode Penelitian \& Pengembangan Research dan Development. Bandung: Alfabeta.

Suhersono, H. 2004. Desain Bordir Motif Krancang, Tepi, dan Lengkung. Jakarta: PT Gramedia Pustaka Utama.

Sulasmini, I Dewa Ayu Sri. 2017. "Kebaya Sebagai Busana ke Pura dalam Representasi Perempuan Kontemporer di Kota Denpasar". Seni Budaya, Volume 32, Nomor 1.

Tegeh, dkk. 2014. Model Penelitian Pengembangan. Singaraja: Graha IImu.
Widianti, Kurnia, dkk. 2017. "Membaca Makna Ornamen Pepatraan Meja dan Kursi di Ruang Pengadilan Kerthagosa Klungkung Bali”. Muara IImu Sosial, Humaniora, dan Seni, Volume 1, Nomor 1.

Yunedi, Gusti, A. 2012. "Motif Patra - Seni Hias Bali" Tersedia pada https://serbaserbihindubali.blogspo t.com (diakses tanggal 2 Januari 2019). 